\title{
Taking Time Seriously: Biographical Circumstance and Immigrant Labor Integration Experience
}

\author{
Erika Gubrium $^{1}$ (D) Mariann Stærkebye Leirvik ${ }^{2}$
}

Accepted: 30 March 2021/Published online: 18 May 2021

(C) The Author(s) 2021

\begin{abstract}
The article offers a re-conceptualization of the labor integration process which takes temporality into account as a relevant feature that, rather than following patterned frames of reference, is actively referenced through narratively and socially constructed formations of understanding. The European policy strategy regarding immigrants has shifted in the past decades from a focus on social integration to a predominant focus on labor market integration, due in part to the relatively high unemployment rates of immigrants entering and migrating within Europe. A personalized approach used throughout Europe to "empower" and move immigrants into the labor market has not been realized in practice. Norway, a "best case scenario" for a more personalized approach through comprehensive labor integration and activation measures, has also had limited success with the sustained labor integration of immigrants. We suggest that a source of the problem lies in the conceptualization of labor integration, which, in contrast to true personalization, follows a patterned notion of the process. We argue that such a conceptualization does not provide the means to explore and untangle potentially significant processes and mechanisms relevant to the labor integration experience. We introduce the concept of biographical circumstance to demonstrate how immigrant participants in a Norwegian labor activation program draw on different references from their personal histories as they make meaning of their labor integration-and how meaning-making is dialectically shaped and delimited by the structural effects of changing policy opportunities, rules, and regulations. We conducted 14 qualitative interviews with immigrants involved in the Norwegian Qualification Program, a national labor activation program. We select four participants to present as illustrative
\end{abstract}

Erika Gubrium

erika.gubrium@oslomet.no

Mariann Stærkebye Leirvik

mleirvik@oslomet.no

1 Department of Social Work, Child Policy and Social Welfare, Oslo Metropolitan University, PO Box 4, St. Olavs plass, Oslo, Norway

2 Norwegian Institute for Urban and Regional Research, Oslo Metropolitan University, Holbergs gate 1, 0166 Oslo, Norway 
cases of biographical circumstance and meaning making. The four differently make meaning of and respond to their labor integration experiences through active reference to specific personal histories and changing policy encounters over time. The data demonstrate that accounting for biographical circumstance enables us to better understand the actions, rationalizations, and motivations of immigrants participating in labor integration and activation measures.

Keywords Immigrants - Laborintegration · Norwegian activation - Norwegian integration · Temporality · Qualitative methods · Narrative analysis · Dual frame of reference ·

Biographical circumstance

It was lost to sight but kept in memory. - Augustine, Confessions ${ }^{1}$

\section{The Problem}

The European policy strategy regarding immigrants has shifted in the past decades from a focus on social integration to a predominant focus on labor market integration, due in part to the relatively high unemployment rates of immigrants entering and migrating within Europe (Karlsdóttir et al., 2017). Making immigrants "productive," especially those who have migrated for protection, is, however, a logistical and ethical challenge. Tailored or personalized welfare services were proposed 16 years ago in the European Employment Strategy as a potential solution to this dilemma (Council of the European Union, 2005). A personalized approach would enable focus on "the empowerment of job seekers," and was to be characterized by "an emphasis on building trust, understanding and responding to individual needs and ultimately instilling ownership for the process" (European Commission, 2012, p. 3). This aim has not necessarily been realized in practice (Hill \& Hupe, 2002). For instance, early adopters of personalized activation, such as the UK and the Netherlands, have, in practice, moved toward or further consolidated a more restrictive and sanction-oriented workfare approach (Lødemel \& Gubrium, 2014; Lymbery, 2013; van Berkel \& Valkenburg, 2007). ${ }^{2}$ The limited realization of the empowering aims of personalization has been attributed to a market-based and work-only-oriented ethos that has both undergirded and undermined such a movement (Daguerre, 2007; Khoronzhevych \& Fadyl, 2020). We suggest, however, that the problem runs deeper and is rooted in how labor integration itself is conceptualized.

Norway is often considered a "best case" scenario for the labor integration and activation of its immigrants (Tronstad, 2016), also in comparison to its Scandinavian neighbors (Hernes et al., 2020). It has a comparatively generous welfare system and

\footnotetext{
${ }^{1}$ As cited in Casey (1983), p. 9.

${ }^{2}$ Workfare is associated with top-down directives and social control. Its main purpose is to sanction recipients via the discretionary application of penalties in order to move claimants back into work as quickly as possible. It is characterized by a tightening of eligibility requirements, with an ultimate restriction in the level benefits offered (Lødemel \& Moreira, 2014).
} 
provides extensive integration measures for refugees granted asylum and their family members. Norway's Introduction Program offers basic language and cultural training within the first years of legal residence (Djuve, 2015; Hernes et al., 2019; Norwegian Ministry of Education \& Research, 2003). Norway's labor activation policies, targeted more broadly to those located far from the labor market, also follow a capacity-building "human capital development" (HCD) strategy (Gubrium et al., 2014), standing in contrast to workfare. Norway's national labor activation program, the Qualification Program, is a cornerstone of the country's HCD strategy and has been touted by the EU and by international observers for its provision of "intensive personal support" for its participants (Duffy, 2010; 15; Prins, 2009).

Nonetheless, Norway's comprehensive integration and activation strategies have not prevented the development of the sorts of dualized labor market outcomes seen in the rest of Europe. The Norwegian labor market possesses a growing divide between "insiders" in well-regulated employment and "outsiders" with precarious positions, higher employment-related risk, and limited rights (Kavli \& Nielsen, 2020). Refugees and family-reunified immigrants in Norway often fall into the latter group (Bratsberg et al., 2018). This outcome is not significantly or sustainably changed with participation in the Introduction Program (Djuve \& Kavli, 2019; Liebig \& Tronstad, 2018) or in more broadly targeted labor activation programs, including the Qualification Program (Norwegian General Auditor, 2019). Many participants instead end up in a continual series of government sponsored "internships" or, at best, find work in more precarious employment (Kjelstad \& Nymoen, 2004; Maximova-Mentzoni, 2019; Nicolaisen \& Kavli, 2020), without access to the rights and protections of the standard Norwegian labor market (Kavli \& Nielsen, 2020; Kleppe \& Støren-Vaczy, 2019).

\section{The Challenge}

The limited success found even within Norway's "best-case" policy situation suggests the need to re-examine how we think about immigrant labor integration. While policy documents have called for a personalized approach, there has, in fact, been little recognition of the specificities of varied lives and life courses. Rather, there has been a pervasive tendency to analyze labor integration according to a strictly linear notion of movement forward over time into an increasingly integrated state. Immigrants are envisioned to start over upon entry into receiving settings, and to move forward on a trajectory eventually leading to work, and thus integration (Fangen, 2010).

The labor integration literature takes a more nuanced stance. Scholars in the field have distinguished between the objective integration of immigrants, which reportedly mostly moves forward, and their subjective "sense of integration," which often does not (reviewed by Hendriks \& Burger, 2019). The literature that refers to a "dual frame of reference" furthermore accounts for temporally mediated aspects of integration. Time is conceptualized as an independent variable determining immigrants' acceptance of a relatively low socio-economic position in the receiving setting (Pietka et al., 2013; Ruhs \& Anderson, 2010). Time, aspiration, and subjective well-being are said to interact in two ways (Hendricks \& Burger, 2019; Stutzer \& Henne, 2014). In the first, immigrants are willing to accommodate a relatively lower status in the short run, but this willingness decreases in the long run, because over time - as they are increasingly 
integrated into the receiving setting - they increasingly assess their status and goals with a frame of reference based on the local standards of the new setting (Anderson 2010; Datta et al 2007; Piore, 1979; Waldinger \& Lichter, 2003, reviewed in van Ostaijen et al., 2017, p. 5). In the second, immigrants persist in accepting a lower status in the receiving setting because they continue to look "back," while also being increasingly integrated into the new setting. They compare their current lives with their earlier lives in a comparatively poorer sending setting, and they look out, comparing their lives to those peers who still reside in the sending setting (Friberg \& Midtbøen, 2018; Koopmans, 2010; Korbøl \& Midtbøen, 2018; McCollum \& Findlay, 2015; Rye, 2012; Wills et al., 2010; Zhang \& Sanders, 1999). In both versions, integration increases over time and the process of comparing life "now" versus "before" and "here" versus "there" results - at least in the short term - in a positive "buffer" and motivator as immigrants cope with otherwise difficult, even untenable, life situations.

We call into question a pattern-based conceptualization of the labor integration process, arguing that it does not provide a meaningful picture of how the subjectivities of immigrants seeking work and working are dynamically constituted. Such a framebased focus leaves little room to explore and untangle potentially significant processes and mechanisms relevant to the labor integration experience. We suggest that the immigrants do not adhere to patterns of understanding that fall into place over time.

Rather, following the quote from Augustine, immigrants actively make meaning of and react to their labor integration experiences through reference to the specificities of their lives, in terms of both personal histories and their policy encounters.

We borrow from more recent sociological conceptualizations of time as being actively referenced through narratively (Holstein \& Gubrium, 2007) and socially constructed (Gergen \& Davis, 1985) formations of understanding. We propose an analytic approach to labor integration that takes seriously such active meaningmaking over time. Immigrants make meaning of their everyday realities interactively and within certain circumstances. As Gubrium and Holstein (1995, p. 209) note, such meaning making "has considerable free play, but it is also oriented to practical, contextual considerations that prevent life course constructions from being capricious or arbitrary." Immigrants who participate in labor integration programs are situated in a changing nexus of immigration and labor activation regimes. Furthermore, policy rules and regulations significantly shape and delimit immigrant employment experiences and decisions (Könönen, 2019). The time period within which an immigrant enters and settles in a receiving setting and the policy offers and priorities characterizing that period are arguably significant in shaping the labor integration experience, including the system-level opportunities and limitations that they might encounter.

We introduce the concept of biographical circumstance to account for the dialectical nature of the labor integration process. The concept focuses on the active and changing personal subjectivities of immigrant interview participants with reference to time, as these are constituted within and are shaped by changing policy landscapes. We argue that this merged analytical concept better represents the complexity of the labor integration process of the research participants - immigrants who were engaged in work-seeking and work activity within the Norwegian Qualification Program in the 2000s and 2010s, years during which the Norwegian activation and immigration systems underwent substantial change. Applying this dialectical focus, we ask the following: How do immigrants make meaning of labor integration processes, with 
reference to changing personal histories and encounters within Norway's activation and integration systems over time? We aim to demonstrate how immigrant participants draw on different references from their personal histories as they make meaning of their labor integration - and how meaning-making is shaped and delimited by the structural effects of changing policy opportunities, rules, and regulations. Through a focus on biographical circumstance, we gain a better understanding of the variation in the understandings and behavior of immigrants participating in labor integration measures.

\section{Activated Assimilation: a Changing Policy Landscape}

We spoke with the research participants in 2011, following a massive overhaul of the Norwegian welfare system. Immigrants who enter Norway for purposes of asylum or for family reunification with settled refugees typically access the Norwegian welfare state at its bottom rungs. The 2000s saw the opening of Europe to immigrants from former Eastern Bloc countries and, in the mid-2000s, a rise in immigrants entering Norway for asylum (Friberg \& Midtbøen, 2018). In Norway, as across Western Europe, the political rhetoric directed towards these immigrants and their family members moved from a vague notion of multiculturalism and social protection to a call for their sociocultural assimilation and labor market entry so as to become "productive" members of Norwegian society (Schinkel, 2018). The policy frameworks that emerged followed suit (Djuve, 2015; Midtbøen, 2017).

Policy movement towards a strategy of "activated assimilation" was first marked in 2004 with the national establishment of the Norwegian Introduction Program (Ot. Prop. nr 28, 2002-2003), and again in 2007 with the national establishment of the Qualification Program (St. meld. nr 9, 2006-2007). Both programs were introduced in response to publicly perceived "crises" in unemployment and welfare dependency within the lower levels of the welfare system. The unrolling of both was punctuated by the 2006 "NAV Reform," the largest governance reform ever in Norway's welfare system history. The reform merged the previously separate state agencies of social insurance and employment services with local authority social assistance provisions and activation measures. With this merger, individuals entering the bottom tier of the welfare system for the first time encountered the sort of employment ideologies and human capital focused activation programming that had before been reserved only for the short-term unemployed (Gubrium et al., 2014).

On an everyday level, policy change was reflected in the vastly differing encounters with the welfare and immigration systems experienced before 2004, versus after 2004 and beyond by immigrants entering Norway from outside the EU. Those entering Norway before 2004, upon receiving right of residency, either entered work or had access to local social assistance provisions. Labor activation programming at this level, if present, was limited to municipal workfare arrangements, with little focus on skillsbuilding or human capital development (Dahl, 2003). There was no distinctive integration measure and no formal offer for Norwegian language acquisition. Beginning in 2004, immigrants granted asylum and the adult family members joining them had the "duty and right" to participate in a 2-year Introduction Program, which provided language, sociocultural, and work training. 
Since 2007, all immigrants - including those with asylum who have been in Norway for more than 2 years - potentially have access to the one-to-two-year Qualification Program. The Qualification Program is explicitly modeled after the Introduction Program, but with a broader target group, including Norwegian citizens and other residents who are long-term recipients of social assistance. The program has represented an offer of "more" for the target group, in terms of higher benefit levels, improved services and the daily schedule and benefits associated with regular work life (Gubrium et al., 2014). Notably, and following the personalized approach outlined at the European level, the Program is to begin with a "systematic analysis and mapping" step, in which the participant provides a self-evaluation and the caseworker evaluates the participant's "competence, possibilities, wishes, and characteristics" (Nordic Board of Health Supervision 2015, p. 9), in order to then write an individualized plan. Yet while Qualification Program participants are "entitled to" an individualized plan, only workrelated measures are guaranteed (Social Services Law nr 81 (revised 2007), Sec. 5A-5). The offer of capacity-building "training, motivation counseling, skills training, etc" depend on local circumstances (Bryn, 2008; ibid, Sec. 5A-2). Evaluations of the Qualification Program demonstrate that aims to personalize have, in fact, been limited in practice. One comprehensive review reports that the situation of participants "not been mapped well enough" and that many municipalities do "not offer satisfactory individual tailoring; the program consists for example of standardized courses or measures that do not correspond with the participant's needs" (Norwegian Board of Health Supervision, 2015, p. 3).

\section{Method of Procedure}

We recruited 14 research participants ${ }^{3}$ for one-to-two-hour, in-depth, semi-structured interviews. The following criteria were used to select participants. All were or had recently been engaged in the Qualification Program and were recruited either directly or indirectly through Program caseworkers. All were immigrants, born abroad to two foreign-born parents and all had been in Norway at least 5 years. Participants ranged in age from 30 to 58 years-old and came from the following sending countries: Gambia (1), Iran (1), Iraq (2), Kazakhstan (1), Pakistan (1), the Philippines (2), Slovenia (1), Somalia (1), Russia (1), and Thailand (3). Most had moved to Norway as adults, but several had as children. Several, also, had life courses that were characterized by "temporary" migration to and from Norway. They had varying levels of education, from several years of primary to completed tertiary education. They also had varying professional backgrounds, ranging from very limited to extensive work history, also at upper levels of the labor market. Six were married, eight were single; among these, three were separated or divorced.

Research participants were given their choice of interview location - most chose the local welfare (NAV) office where they were or had recently been engaged in program activities. The interviews focused more broadly on the participants' lives, on how it was to live on a low income in Norway and on their experiences with the Qualification Program. We coded the interviews by hand and analyzed them with attention to how

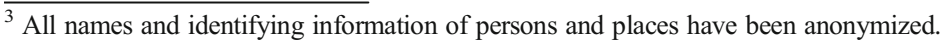


participants made narrative linkages (Gubrium, 2008). Our focus was not on cataloguing the labor integration experiences described by the participants, but rather on how such experiences were made meaningful by the participants through specific linkage to their biological circumstances - to their personal histories, both before and after migrating to Norway, as well as to their encounters with the welfare and integration systems.

Our analysis followed a case study design (Stake, 1995). Following a case-study approach, our analytical goal was thus not to reach data saturation to present generalized results, but instead to demonstrate the diversity of meaning-making and response to the labor integration process (Yin, 2009). Out of the 14 interviews analyzed, we select four participants to present as illustrative cases. They represented experiences and described themes common to the 14 participants, but also possessed distinct biographical circumstance profiles - differing in past status, professional and personal history, immigration pathway, life course ruptures, and history of welfare and integration system encounters and opportunities. The four cases of biographical circumstance are illustrative of the dialectical and active nature of the labor integration process.

In the next section, our findings are divided into three parts, each presenting a dominant theme related to labor integration experience emerging from the 14 interviews. Within each part, we present and contrast the narratives of two research participants, to exemplify the active use of distinct biographical circumstances when making meaning of and responding to labor integration experiences.

\section{The Findings}

Three themes pertaining to labor integration over time strongly emerged from the fourteen interviews. Despite the emergence of these common themes, participants referred to varying biographical circumstances to make sense of their labor integration experiences in different ways.

\section{Changed Status: Reflections on "Then" and "Now"}

Participants actively referred to and compared past statuses when making meaning of their current work trajectories, contrasting earlier points in their biographical histories to their currently situated identities and status in the Norwegian welfare system. Many engaged in such comparison work described a loss of status after migration and described the change in status as a distinctly negative experience. They differed, however, in how they understood their current work-oriented activities.

Samira, ${ }^{4} 41$, stands out from those of the other three participants presented. Her life course was discontinuous, as she had moved back and forth between Norway and Pakistan several times. She had immigrated from Pakistan with her parents when she was 10 and had "grown up" as a "third-culture kid" (Naqvi, 2019) in Norway. While a young adult in Norway, she had earned a high school degree, had begun courses in programming and data entry and had worked briefly as a grocery store cashier. After

\footnotetext{
${ }^{4}$ All names and identifying information have been modified to protect the confidentiality of the research participants.
} 
marrying, she had moved back to Pakistan with her husband and children, due to her husband's health problems. The family had stayed in Pakistan for 10 years, where Samira had spent her time at home, raising the children, 12 and 19 at the time of the interview. She and her family had moved back to Norway several years before the interview took place. She was fully fluent in Norwegian, but her years spent outside the workforce while in Pakistan were an obstacle to finding employment and she was enrolled in the Qualification Program.

In the following excerpt, Samira compares her changed status over the past years to the statuses of her tightly knit broader family and friend network. As she notes,

I have my family here, my parents and my siblings, and things are going well for them, they're highly educated and have good jobs and they manage well. Plus, my friends are doing well. All of them have jobs and nice houses. ... It's not going so well (for me), it doesn't feel really good, at the very least, when I'm with them. Especially with family. ... When I used to live here, I had my own apartment and we sold it when we moved to Pakistan. Now I find myself really behind in relation to the people I compare myself with. I don't have many (friends). (With the friendships that were maintained), since I've been gone so long there's become a much larger... distance, you know? They think differently, I think differently, we think differently. But fortunately, our childhoods were the same. ... Nonetheless, they've just gone on vacation (to Pakistan). I'm the one who stayed longer.

Samira draws on her past as a youth and young adult in Norway, where she was earlier on the same status level as her friends and family. She places herself within the social hierarchy by drawing on a contrast between her struggle to find work and make a nice home for her family and the circumstances of her Pakistani friends and family members who have remained in Norway, circumstances that also used to be hers. For Samira, it is the distance between what "should be" and "what is" that is especially difficult. Her peers in Norway have experienced upward social mobility, while she has not. She emphasizes that her experiences do not fit the standardized expectation of class travel for a second-generation immigrant (Hermansen, 2016). While her siblings and friends have higher educations, good jobs, and earn good incomes and own their own houses, Samira is, because of years spent in Pakistan as an adult, outside this collective story. She feels forced to undergo the experience of migrating once again to the same country she migrated to as a child, this time as an adult. Throughout the interview, she emphasizes the difficulty of negotiating the different identities she has experienced over time and in different settings: "being Norwegian as a kid," feeling "different" as an adult, and interacting with the Norwegian welfare system as a newly arrived immigrant. She simultaneously is not able to draw on a status as a "new" immigrant to Norway in order to rationalize her situation and is unable to translate her command of Norwegian and of Norwegian culture into a resource for finding work through the Qualification Program. She is "from" Norway, is fully fluent in the native language, and has a tight social network around her. She emphasizes how she must reconcile her aspirations growing up in Norway with her feelings of "difference" and reduced employment possibilities now. While her migration experience as an adult means that she has had to start over, she also feels immense pressure to "catch up" with her peers, and she is keen to gain work experience through the Program's work trainings. 
Unlike Samira, who describes her earlier decision to leave Norway as a rupture point in her life course leading to downward status mobility, Pouneh links her loss of status - professionally and personally - to migration to Norway and the family troubles and system-level bias that has followed this decision. Pouneh, 49, sought political asylum in Norway from Iran 14 years earlier, when she was 35 years old, joining her Iranian husband. At the time of the interview, she did not communicate fluently in Norwegian. Pouneh had entered Norway long before the establishment of the Introduction Program and thus had had no formal offer or requirement to take language or work-seeking courses in after settling in the country. She had spent her first years taking care of her husband, whose mental health had dramatically deteriorated and who had grown increasingly abusive, as well as assuming primary care for her young son. She noted that her intensive family care work in these early years had left little opportunity to find work or learn the language. At the time of the interview, Pouneh's family ties had weakened considerably. She had divorced her husband, who had moved back to Iran, and her son, then 12, had several years earlier been "kidnapped" by the child protection authorities and placed in foster care. Unlike Samira, Pouneh had earlier had an extended, high-status work history in her home country, where she had owned a gardening business.

At the time of the interview, Pouneh was almost finished with the Qualification Program, where she had been involved in a series of work trainings that had not led to regular employment. In the following excerpt, she recalls her professional history as a business owner earlier in Iran when making sense of her current activities in the Qualification Program, including participation in a series of work trainings organized through the program and taking place at a local garden center. As she notes,

I've been a trainee at Pretty Plants (garden center). Before that, I took courses... from NAV. They don't help at all. ...For example, I've been a gardener for 15 years. I had my own nursery in Iran. I just don't have an (official) certificate. ... It's not easy if you don't have formal education from Norway. The professional leader at Pretty Plants says, "You're just like me". The leaders (say) "your experience is the highest I've ever seen". I identify plant illnesses, I set out the plants and then they're sprayed. The leader at Pretty Plants is completely satisfied. But he won't (hire me), he's looking at his budget. He's counting his money. ...From 2010 to today (1 year), I've only had training after training position...it's hopeless. Every time they praise me: "You are very smart, you are great!" But you can't buy food with praise.

When making meaning of her current professional status, Pouneh, who has experienced personal ruptures in her life both before and after moving in Norway, does not make heavy reference to a family or peer network, as Samira does. Instead, she refers to her relatively low status within the Norwegian workplace and labor market, as well as within the Norwegian welfare system, and contrasts this with her former professional status in Iran. She identifies with the leaders at the business where she has her work training post and treats them as who her peer group ought to be, given her high level professional experience in the same sector. Pouneh emphasizes the disconnect she experiences being placed in a quite 
different peer group by the Norwegian welfare authorities (NAV) - with other work trainees, many with little work experience. Through this comparative work, she suggests that her current work-oriented activities do not represent a path towards gaining skills or employment in her area of expertise, much less to finding a regular job. Her encounters with the Norwegian welfare system have resulted in participation in a series of low-skill job training positions rather than the acquisition of the necessary language skills and professional credentials needed to engage in higher-level, or even regular, work. She emphasizes her lack of hope and cynicism after encounters with an institutional logic that "everyone starts with a blank slate," and the notion that she must accept finding herself on the bottom rung of the welfare system hierarchy. Her experiences having already lost a son to the child protection authorities make it even more difficult for her to "fail" to overcome the system's rigidity.

\section{Personal and Professional Aspirations: Linking Past and Future}

Participants made strong narrative connections between past and future aspirations when making meaning of work and work-seeking. They described a sense of dissonance between earlier hopes and possibilities and welfare system aims that did not match. The inability to realize aspired identities, relationships, and statuses heightened feelings of personal failure and many also described a sense that the system had failed them. Their strategies for dealing with this feeling, however, differed.

Sanjay, 33, had gained asylum in Norway, moving from Iraq eleven years earlier, in 2000, at the age of 22. He had arrived in Norway before the Introduction Program was established, and he therefore did not receive a formal offer for language or work training during his first years in the country. He had found low-skilled, temporary work cleaning cruise ships shortly after settling in Norway. After 7 years, Sanjay lost this job after the cleaning business went bankrupt. By this point, he was married and had two young children, with a third on the way. He had chronic pain that he attributed to the physical demands of his cleaning work, and he had decided to switch to a job with fewer physical requirements. It was, however, difficult to find work and he had therefore entered the Qualification Program. He was, however, on medical leave from the Program when we spoke with him.

Sanjay was easily able to communicate in Norwegian, despite having arrived before Introduction Program and its offer of language training, and despite having worked for years with immigrant co-workers and thus with limited access to Norwegian speakers. As he notes,

At work... there were almost 50 employees, all of us foreigners. We just spoke Arabic (with each other). Maybe one...or two times a week, we would speak (Norwegian) with the boss, but not often (laughs). ...I was very smart at school...back in my homeland. Then. And I read all the time. So, since I've been in Norway, I've had the strategy of reading... and following shows on TV. Reading books and the newspaper, that sort of thing. 
Sanjay refers throughout the interview to his former identity as "smart" and with a "promising future," suggesting that he had hoped to achieve a higher socioeconomic status earlier in life, when in Iraq. He refers to this past identity when explaining his ability to find work and learn the Norwegian language without the formal training or support. Maintaining a semblance of his former promise was important to Sanjay, and he refers throughout the interview to his ability to provide his family with middle-class material conditions, including "owning a car," and "owning an apartment." He contrasts this identity as a quick learner and hard worker with his current necessity to depend on the Norwegian welfare state for help, a need that he describes as extra pressing with a family to help support. Sanjay compares himself to other Iraqi friends in Norway, who are working and with lives "on track." He has already lowered his earlier scholarly aspirations, having taken employment in a sector characterized by highly physical and tenuous work, where his colleagues were also immigrants. Unlike his peers, he is not able to maintain even his reduced aspirations for a secure, middle class existence. In recent years, and reflecting the tenuous nature of his work, his employer went out of business and his professional trajectory has suffered an even further hit. His employment options in the low-skilled sectors accessible to him are limited because of work-related physical ailments.

Because of medical issues, it was possible that Sanjay would not be able to complete the Qualification Program. He describes an imagined near future, in which the only option open to him is reliance on social assistance. As he notes,

Maybe after a year it will happen...I will just have to go on social assistance, even though I own an apartment... and my wife works. I don't know how they'll count (my assets). ...For example, I have a car. Maybe...if I go to the social assistance office, social assistance will say, "no, you must sell your car". You know? ...I'm not in my homeland then, to put it one way. (It will be expected) that I should sit at home without a car. I have a family, we have to have a car, regardless. That's why I never go to social assistance. ... I've also thought about the apartment, that we've soon lived here four years. ...We're really happy there and I hope I can (continue to) have the apartment. ... But maybe if I go on social assistance they'll say, "No, because you have a bank loan and interest", or something. So, I never go to social assistance.

Throughout the interview Sanjay refers to earlier statuses and identities as he evokes a sense of movement downward through the welfare system and social hierarchy. He contrasts his past situation of full employment and middle-class lifestyle with the reality that he will likely have to move even further away from an identity as the "smart one who will manage well." In a future spent on the lowest rung of the welfare hierarchy, Sanjay expects that he will be forced to reduce his aspirations, his lifestyle, and his status even further, to fit with the stigmatized status associated with social assistance. He considers himself a "failure," in terms of both who he hoped to be when in Iraq and who he hoped to be once in Norway. Nonetheless, he is still relatively young, and, referring to his identity as a family provider throughout the interview; he is motivated to try to maintain his family's current living standards by obtaining a professional chauffeur's certificate through NAV. 
Unlike Sanjay's promising future while still in his home country, Suchin, 30, had left a life in poverty in her home country of Thailand. She had moved to Norway four years earlier, in 2007, to join her Norwegian husband. Suchin had a high school certificate and low-skilled work experience in Thailand and had taken temporary work in the service sector in Norway while still married. After her marriage became abusive, she left her husband and had not been able to find work since. As she had entered Norway via family reunification with a Norwegian citizen, she had not had access to the Introduction Program. She had taken a short language course offered privately and had difficulty communicating in Norwegian.

Suchin had recently finished the Qualification Program with no job prospects. At the time of the interview, she was single and divorced, with no children and, unlike Sanjay, referred to herself as "all alone" in Norway. Throughout the interview, Suchin primarily makes sense of her experience in the Qualification Program by contrasting this identity with an earlier identity as a daughter, sister and friend. "Before" she was the good daughter who worked to support her family. In Norway, the family she had expected to build has been lost, both through a shattered connection to her ex-husband and through the large geographical distance now existing between herself and her family in Thailand. In the following excerpt, Suchin links finding work to the reparation of a lost social connection she feels and to the ability to feel a sense of belonging in Norway. As she notes,

When I'm in Thailand I feel (comfortable) being in the society, being with friends and talking. It's only the finances that are difficult. But here (in Norway), it's difficult with the society, the language, friends - there's a little less of it - very little social (activity) for me. ...I feel small in Norway. I can't get to know Norwegian people. ...Maybe if I had work, then we could be friends. ...Sometimes I think too much. Get sad, depressed. I'm worried about the future, about what I'm going to do, and...sometimes I get like, "No, I can't take any more" and so forth. ...I have to find a job.

As with Sanjay, Suchin contrasts her past aspirations to her reduced current ones. Unlike Sanjay, however, she does not have a work history or personal network in Norway. Instead, she describes her reduced circumstances through reference to a personal support network that she has lost. She links her work-seeking activities to a possible future in which she might find comfort in the broader society within which she lives. As she continues,

I want to live here. I think there's a better chance for the future, for a better life. If it's possible, I would of course like to live together with my family. My mother and my sisters...if I can take them with me. I want to bring my sister (to live with me in Norway) in the future. If I have my own job and own apartment, then I can bring her with me here. (She can) go to school here. She's 8 years old. So, it's possible to bring her here. And to live together. ... So that I can have some family here. 
For Suchin, as for Sanjay, finding work in Norway and earning money is not an end in itself - their aspirations are not merely focused on entering employment and earning an income. Both look back to earlier and forward to an imagined later when making meaning of their participation in the Qualification Program. Both describe their move down in status, but each refers to differing circumstances, and therefore, to different motivations. Sanjay emphasizes his changing status within his local community, within the labor market and within welfare hierarchy when describing his reasons for seeking work. Suchin refers primarily to past social and personal identities, directly connecting work-seeking to her hopes of (re)building a family and social network in the future.

\section{The Materiality of Time: Wasting Time and Lost Time}

The research participants operationalized time as a resource that was either provided or taken away by the welfare system and its activation measures. They emphasized the idea of "wasting time" when describing work-related activities that did not match their personal aspirations or felt status. They referred to "lost time" and described a strongly felt sense of a "ticking clock" when attempting to regain lost ground after moving to Norway. The sense of wasted or lost time heightened their sense of material deprivation.

Later in the interview, Pouneh recalls again her past status, referring to herself as "a gardener for 15 years" and as head of her "own plant nursery in Iran." Through the Qualification Program, her series of work training positions at a local garden center have each ended without a job offer. The familiar terrain has only served to heighten the dissonance she experiences between her earlier identity and her current situation as "free labor" in the same industry. As she notes,

At Pretty Plants, where I work (as a trainee), I received an award because I'm a very good gardener (displays an award for best employee). But my employer says, "no, sorry, but we have a bad budget". Yet every single day they have a million kroner extra (surplus). (The employer says) "You're very good, you have complete overview of the plants", but they won't make me permanent. They only say that it's only a seasonal job... The employer has a work training position for me. I'll never be made permanent. I've worked like a slave and worked every single day. From 8 o'clock to 1630, I work at Pretty Plants. They need me, but I'm only a trainee. It's free (for them).

Pouneh's downward trajectory is especially marked given that she is working in the same sector as she did when in Iran. She emphasizes throughout the interview her hard work ethic, also bringing evidence of this with her, as proof that it is reasonable to expect regular employment. She narratively contrasts her work capacity with her current identity as a "slave" to evoke her sense of powerlessness within a sector where she was formerly a business leader.

Pouneh continues, describing her limited options, noting,

I think the work training positions are really just bullying ... My training position has become a permanent situation. ... I'm not so young. Ninety percent of the 
workers are Swedish who have come to work, but they're inexperienced. ... Only I have been a gardener before or... a professional. ...It's...the boss who counts money, they don't see the person...Many times I've...talked with my caseworker... about opening my own business. Or asked if NAV could help me to find the right school, so I can get my professional certificate. And (my caseworker) says that if you go to school you have to have wages, because it'll be very expensive for you. I can't do that. NAV doesn't help. All the paths are closed for me.

Pouneh refers to her age and her ethnicity when describing her "wasted" time as a work trainee and when concluding there are no more "paths" for her into the labor market. She emphasizes a sense of wasted time by describing how her past identity has been degraded over her time in the NAV activation regime. In contrast to earlier, "now" she is expected to identify with her younger, "inexperienced," Swedish co-workers. She emphasizes this contrast to explain her sense of demotivation. She has years of experience in a secure, higher-level position, yet she feels she is at end of her work trajectory. She has given up hope.

As did Pouneh, Sanjay had a higher socioeconomic status in his home country, but unlike her, he had been younger when migrating and he had had a more modest professional history before moving to Norway. He had first arrived in Norway alone as a young adult. Sanjay refers to "difficulties before", to a personal history of difficulties that forced him to leave Iraq and to having to seek refuge in Norway, when making sense of his current situation. Drawing on these difficulties and the uphill battle he faced when first in Norway, he proudly describes how he found work early on in Norway. While precarious and below his earlier level of aspirations, he considers having found any work at this point as something of a victory. Years later and in his current circumstances as a father, husband, and settled member in his local community, his expectations concerning employment are higher. "Now," he "still faces difficulties," but of a different, more relative, nature. Despite working hard for years, he has not found stable work. He has entered the Qualification Program to maintain the status and networks he has managed to build, but the Program has not helped him to find stable work. He describes the time he has spent, noting,

The only offer I've gotten through NAV, has been... a truck driver's course. ...It will give me a slightly higher (wage)... if I...find work in a shop or a storage facility, for example. I was supposed to begin the course, but... a day before the course started, I talked with NAV to check on things... and they said, "No... you're not one of the people chosen to take the course." I said, "But I have a letter from you, it's signed by both you and me", but they say, "There's been a mistake, you can't participate in this course." ... That's the only thing I've gotten (laughs). ...I have to be honest, from my side...I was ready (to work) the first day I lost my job...I don't know what NAV is doing, plain and simple. ... I don't have lots of experience here....in Norway, so I figure it'll stay this way.

Sanjay draws on his identity as a hard worker when making meaning of his workseeking activities in the Qualification Program. He emphasizes his identity as a willing worker when describing frustration at having been unemployed for three years despite 
being "ready the first day" after losing his job, and then having wait to receive the necessary training through NAV. This is not the end of the story for Sanjay, however. He is willing to bide his time and hope that the system will respond at some point.

Pouneh and Sanjay make different meanings of the time used to attain the necessary credentials for skilled work. Their encounters with the welfare activation and immigration systems are similar, but their work histories, ages, and stories of life rupture differ. Pouneh emphasizes her advanced age and her non-Scandinavian identity when describing her options as limited. Seeing no easy way into the labor market, she understands her time in work training positions as "wasted." Sanjay, with re-adjusted ambitions, has had a regular, albeit low-skilled job history in Norway, and hopes to find modest, but more stable and less physically exhausting work. He is, furthermore, relatively young and feels the pressure to help provide for his family. For Sanjay, gaining the employment he seeks is a matter of waiting to move forward and while he understands his time out of work as time "lost," he may eventually get back "on track."

\section{Conclusions}

We have drawn our empirical material from Norway's "best case" landscape of immigrant labor integration and activation policies. Norway has, as has much of Europe, adhered to a strategy of personalized and individualized welfare measures, tailored to the needs of measure participants in order to best move them into the labor market. Earlier research has suggested that contradictory political ideologies (Daguerre, 2007; van Berkel \& Valkenberg, 2007; Lødemel \& Gubrium, 2014) and institutional mantras (Khoronzhevych \& Fadyl, 2020; Lymbery, 2013) have prevented the strategy from bearing significantly positive results.

Our analysis shifts the focus, arguing that the trouble begins with an overly reductive and deterministic conceptualization of labor integration. A long tradition of social science scholarship has treated the life course as a naturally patterned progression of individual experience through time (Clausen, 1986; Holstein \& Gubrium, 2007). The dominant policy narratives and analytical models pertaining to the labor integration of immigrants also rely on linear explanations of integration, where immigrant subjectivities concerning their labor integration fall into distinct patterns that are temporally determined. We argue that such a conceptualization, reflected most notably in the "dual frame of reference" literature, does not account for the active ways in which people draw upon their changing biographical circumstances to make meaning of and respond to their experiences.

The four research participants presented did not make meaning of their labor integration situations by comparing unified and cohesive temporal frames of "then" versus "now." Rather, when referring to their personal histories, participants contrasted their earlier lives with those today by referring to an assortment of migration pathways, professional and personal statuses, identities, personal networks, skills, and labor market opportunities. They dialectically understood their labor integration experiences: They made meaning of policy encounters through active reference to their specific personal histories, but their labor integration narratives were also shaped, delimited and made in contrast to the institutional offers and limitations they had encountered over time. For instance, the meaning of participation in a series of work training positions with no clear employment opportunities in sight meant the end of a path into work and complete loss of 
motivation for Pouneh, in her late 40s and a "business leader" earlier in life, but with no employment history in Norway and no family nearby for support. It meant frustration, but a willingness to wait for "the certificate" that would enable more stable work for Sanjay, in his early 30s, with a past as "school smart" and an independent learner, but with a work history limited to the precarious Norwegian labor sector, two children to care for and a pregnant wife in part-time employment. For Suchin, in her early 30s, with no family and "alone in Norway," labor integration was as much about the possibility to move her family to Norway as it was about establishing a career. For Pouneh, Sanjay and Suchin, moving to the Norway represented a "rupture" in their life course and they negotiated - to varying levels of ease - their earlier professional and personal aspirations with their current possibilities. For Samira, the move from Norway was where the rupture from earlier aspirations took place. She was in her early 40s with a limited work history, but with a discontinuous life trajectory back and forth between Pakistan and Norway, but also with fluent Norwegian, "roots in Norway" and an extensive family and personal network nearby. Samira connected her labor integration activities to gaining an income, but moreover, to finding a way back to the expected life trajectory of younger self, a process made even more difficult as she had returned "home."

The evidence demonstrates the dynamic character of the immigrant labor integration process over time. Given the invisibility of their lives "before" due to the nature of geographical dislocation, this dynamic nature is, however, easily lost in policy making and analysis. Our approach of analyzing according to changing biographical circumstance differs from the more objectivist approach in that it does not take a meaningful life cycle or set of life stages for granted, but instead places these meanings front and center, exploring how they are constructed in relation to the notion of whole lives (Holstein \& Gubrium, 2007).

A focus on the dynamic nature of biographical circumstance enables us to account for how immigrants actively draw on complex life courses and policy encounters when subjectively making meaning of and responding to their labor integration experiences. We argue that such an accounting therefore enables us to better understand the actions, rationalizations, and motivations of immigrants participating in labor integration and activation measures.

Funding Open access funding provided by OsloMet - Oslo Metropolitan University.

Open Access This article is licensed under a Creative Commons Attribution 4.0 International License, which permits use, sharing, adaptation, distribution and reproduction in any medium or format, as long as you give appropriate credit to the original author(s) and the source, provide a link to the Creative Commons licence, and indicate if changes were made. The images or other third party material in this article are included in the article's Creative Commons licence, unless indicated otherwise in a credit line to the material. If material is not included in the article's Creative Commons licence and your intended use is not permitted by statutory regulation or exceeds the permitted use, you will need to obtain permission directly from the copyright holder. To view a copy of this licence, visit http://creativecommons.org/licenses/by/4.0/.

\section{References}

Bratsberg, B., Raaum, O., \& Røed, K. (2018). Job loss and immigrant labor market performance. Economica, 85(337), 124-151. 
Bryn, MD. (2008). Kvalifiseringsprogrammet: rett medisin mot sosialhjelpsavhengighet? [The Qualification Program: Right Medicine against SA Dependency?], Master's Thesis, University of Oslo.

Casey, E. S. (1983). Keeping the past in mind. Review of Metaphysics, 37(1), 77-95.

Clausen, J. A. (1986). The Life Course. Prentice Hall.

Council of the European Union. (2005). Council decision of 12 July 2005 on guidelines for the employment policies of the member states, in Official Journal of the European Union 6.8.2005, Brussels: EC.

Daguerre, A. (2007). Active labour market policies and welfare reform: Europe and the US in comparative perspective. Palgrave Macmillan.

Dahl, E. (2003). Does 'Workfare' Work? The Norwegian experience. International Journal of Social Welfare, $12,274-288$.

Djuve, A. B. (2015). Multikulturalisme på norsk - Er anerkjennelse til hinder for utjevning? Agora, 02-03, 85109.

Djuve, A. B., \& Kavli, H. C. (2019). Refugee integration policy the Norwegian way-Why good ideas fail and bad ideas prevail. Transfer: European Review of Labour and Research, 25(1), 25-42.

Duffy, K (2010) Active inclusion: a comprehensive strategy for poverty reduction? In D Ben-Galim \& A. Sachradja (Eds), Now it's personal: Learning from welfare-to-work approaches around the world, IPPR Report, August 2010.

European Commission (2012) Activation and integration: Working with individual action plans-Toolkit for public employment services.

Fangen, K. (2010). Social exclusion and inclusion of young immigrants: Presentation of an analytical framework. Young, 18(2), 133-156.

Fernandes, A. G. (2013). Ethnification of new social risks. Palgrave Macmillan.

Friberg, J., \& Midtbøen, A. H. (2018). Ethnicity as skill: immigrant employment hierarchies in Norwegian low-wage labour markets. Journal of Ethnic and Migration Studies, 44(9), 1463-1478.

Gergen, K., \& Davis, K. E. (1985). The social construction of the person. Springer-Verlag.

Gubrium, J. F. (2008). Analyzing narrative reality. Thousand Oaks.

Gubrium, J. F., \& Holstein, J. A. (1995). Life course malleability: Biographical work and deprivatization. Sociological Inquiry, 65, 207-223.

Gubrium, E. K., Harsløf, I., \& Lødemel, I. (2014). Norwegian activation reform on a wave of wider welfare state change: A critical assessment. In: Lødemel, I., \& Moreira, A. (Eds). Activation or Workfare? Governance and the Neo-Liberal Convergence. Oxford University Press.

Hendriks, M., \& Burger, M. J. (2019). Unsuccessful subjective well-being assimilation among immigrants: The role of faltering perceptions of the host society. Journal of Happiness Studies, 1-22.

Hermansen, A. S. (2016). Moving up or falling behind? Intergenerational socioeconomic transmission among children of immigrants in Norway. European Sociological Review, 32(5), 675-689.

Hernes, V., Tronstad, K., Joona, P. A., \& Arendt, J. (2019). Nordic integration and settlement policies for refugees A comparative analysis of labor market integration outcomes. Nordic Council of Ministers, TemaNord, 2019, 529.

Hernes, V, Arendt, J, Andersson Joona, P, \& Tronstad, K (2020) Rapid or long-term employment? A Scandinavian comparative study of refugee integration policies and employment outcomes. Journal of European Public Policy, 1-21

Hill, M., \& Hupe, P. (2002). Implementing Public Policy. Sage Publications.

Holstein, J. A., \& Gubrium, J. F. (2007). Constructionist perspectives on the life course. Sociology Compass, 1, 335-352.

Karlsdóttir, A, Sigurjónsdóttir, HR, Hildestrand, ÅS \& Cuadrado, A (2017) Policies and measures for speeding up labor market integration of refugees in the Nordic region.

Kavli, HC \& Nielsen, RA (2020) Stepping in, stepping out or staying put? Part-time work and immigrant integration in Norway. Chapter 7 in Dualization of part-time work-a story of labour market insiders and outsiders. Policy Press.

Khoronzhevych, M \& Fadyl, J (2020) How congruent is person-centred practice with labour activation policy? Person-centred approach to vocational interventions on immigrant jobseekers in Norway. European Journal of Social Work, 1-15.

Kjelstad, R \& Nymoen, EH (2004) Kvinner og menn i deltidsarbeid. Fordeling og forklaringer. Rapport 29. Statistisk sentralbyrå.

Kleppe, LC \& Støren-Vaczy, B (2019) Temporary employment agencies' role in work inclusion of immigrants and refugees: Opportunities or a permanent precariat? Borch et al. (Eds). Inclusive consumption: Immigrants' access to and use of public and private goods and services. Universitetsforlaget, 119-131.

Könönen, J. (2019). Becoming a 'labour migrant': Immigration regulations as a frame of reference for migrant employment. Work, Employment and Society, 33(5), 777-793. 
Koopmans, R. (2010). Trade-offs between equality and difference: Immigrant integration, multiculturalism and the welfare state in cross-national perspective. JEMS, 36(1), 1-26.

Korbøl, A., \& Midtbøen, A. (2018). Den kritiske fase: Innvandring til Norge fra Pakistan 1970-1973. Universitetsforlaget.

Liebig, T \& Tronstad, K (2018) Triple disadvantage? A first overview of the integration of refugee women", OECD.

Lødemel, I., \& Gubrium, E. K. (2014). Trajectories of change: Activation reforms from inception to times of austerity. In: Lødemel, I., \& Moreira, A. (Eds). Activation or Workfare? Governance and the Neo-Liberal Convergence. Oxford University Press.

Lødemel, I., \& Moreira, A. (2014). Activation or workfare? Governance and the neo-liberal convergence. Oxford University Press.

Lymbery, M. (2013). Understanding personalisation: Implications for social work. Journal of Social Work., 14(3), 295-312.

Maximova-Mentzoni, T. (2019). Kvalifiseringstiltak for innvandrere og muligheter for Supported Employment. Søkelys på Arbeidslivet, 36(1-2), 36-54.

McCollum, D., \& Findlay, A. (2015). 'Flexible' workers for 'flexible' jobs? The labour market function of A8 migrant labour in the UK. Work, Employment and Society, 29(3), 427-443.

Midtbøen, A. (2017). Innvandringshistorie som faghistorie: Kontroverser i Norsk migrasjonsforskning. Nytt Norsk Tidsskrift, 34(2), 130-149.

Naqvi, A. R. (2019). Third Culture Kids (Å vokse opp mellom kulturer). Gyldendal.

Nicolaisen, H \& HC Kavli (2020) Dualization of part-time work-A story of labour market insiders and outsiders. Policy Press.

Norwegian Board of Health Supervision (2015) Summary of a country-wide investigation in 2013 and 2014 of the municipalities' work with the Qualification Program in NAV, Report 2/2015.

Norwegian General Auditor (2019) General auditor's investigation of the authority's work with the integration of refugees and immigrants through qualification to work. Document 3:4 (2019-2020).

Norwegian Ministry of Education \& Research (2003) Law on the introduction program and Norwegian language education for newly arrived immigrants (the Introduction Law).

Pietka, E., Clark, C., \& Canton, N. (2013). I know that I have a university diploma and I'm working as a driver. In B. Glorius, I. Grabowska-Lusinska, \& A. Rindoks (Eds.), Mobility in transition: migration patterns after EU-enlargement. Amsterdam University Press.

Piore, M. J. (1979). Birds of Passage: Migrant Labor and Industrial Societies. Cambridge University Press.

Prins, R (2009) Synthesis report: Developing well targeted tools for the active inclusion of vulnerable people, Norway 29-30 October, ASTRI Research and Consultancy Group.

Ruhs, M., \& Anderson, B. (2010). Semi-compliance and illegality in migrant labour markets: An analysis of migrants, employers and the state in the UK. Population Space Place, 16, 195-211.

Rye, J. F. (2012). «Jeg tror jeg er tilfreds»: Østeeuropeeiske arbeidsinnvandreres vurderinger av norske lønnsog arbeidsforhold. Søkelys på Arbeidslivet, 1-2, 56-75.

Schinkel, W. (2018). Against 'immigrant integration': for an end to neocolonial knowledge production. Comparative Migration Studies, 6(31), 1-17.

Stake, RE (1995) The art of case study research. Thousand Oaks: California: Sage.

Stutzer, A., \& Henne, T. (2014). Aspiration theory. In A. C. Michalos (Ed.), Encyclopedia of quality of life and well-being research. Springer.

Tronstad, K. (2016). Integration in Scandinavia. IMDi-report 2016.

van Berkel, R \& Valkenburg, B (2007) The individualisation of activation services in context, in R van Berkel and B Valkenburg (Eds), Making it personal: Individualising activation services in the EU, Bristol: Policy Press, Ch. 1.

van Ostaijen, M., Reeger, U., \& Zelano, K. (2017). The commodification of mobile workers in Europe-a comparative perspective on capital and labour in Austria, the Netherlands and Sweden. Comparative Migration Studies, 5(1), 6.

Waldinger, R. D., \& Lichter, M. I. (2003). How the other half works. University of California Press.

Wills, J., Datta, K., Evans, Y., Herbert, J., May, J., \& McIlwaine, C. (2010). Global cities at work: New migrant division of labour. Pluto Press.

Yin, R. K. (2009). Case study research, design and methods. Sage Publications.

Zhang, P., \& Sanders, J. (1999). Extended stratification: Immigrant and native differences in individual and family labor. Sociological quarterly, 40(4), 681-704.

Publisher's Note Springer Nature remains neutral with regard to jurisdictional claims in published maps and institutional affiliations. 